\title{
Quality assurance in Vietnam's higher education: Insights into past and present challenges
}

\author{
Thu Dau Mot University
}

\author{
Nguyễn Văn Hiệp,
}

\author{
Email:hiepnv@tdmu.edu.vn
}

\begin{abstract}
Vietnam higher education has attempted innovations in increased efforts to integrate well into the world's education. One of the most prominent innovative activities is quality assurance. Adopting a historical approach, this paper presents the Vietnam higher education quality assurance renovating process including three phases: the centrally planned economy period (1954-1986), the reform period (1986-2000) and the international integration period (2000-2017). At each stage, it is referred to the perspective, the system, the mechanism, and the achievements of Vietnam higher education quality assurance. By taking a historical stance, the paper presented the continued advance of higher education management, the role and significance of quality assurance as an integration commitment of Vietnam education in the context of globalization.
\end{abstract}

Keywords: higher education, quality assurance, training, Vietnam

\section{INTRODUCTION}

Quality assurance in higher education has a development history over two centuries. In the early of the 19th century, countries such as England, France and Italy applied quality assessment standards to verify the quality of universities (Charles, 2007). In United States of America, the quality control system was first implemented in 1905 (Nga, 2010). Towards the end of the 20th century, in the trend of globalization, the education quality has become a common trend in most countries, not only in developed countries in Europe (Netherlands, Belgium, Germany), but also in developing countries in Asia, Latin America and the Gulf region (Oman, Kuwait, Qatar, Arabic Saudi, Chile...) (Quyen, 2017). Quality assurance activities relate to the management mechanism as well as the activities of a higher education institutions. The quality assurance of a higher education institution will provide the community, particularly the students with the assurance that the institution satisfied with students' requirements. Quality assurance activities also represent the national culture context and its higher education development (Cuong, 2017).

Quality assurance in Vietnam's higher education has received increased attention and become a major mission at both management and training organizations. Quality assurance survey assesses achievements or problems of quality assurance activities thereby it can improve training program. Through quality assurance activities, researchers have more documents to assess the degree of integration of Vietnamese higher education into the world education in globalization. This paper presents research result on the quality assurance of Vietnamese higher education in a three-stage process based on the perspective of the quality of higher education, namely the central-planned economy, the reform period, and the international integration.

\section{Literature review}

On a global scale, research in higher education quality assurance activities have paid attention studies on quality assurance models in functionalism perspective (Harvey and Green, 1993; Vlăsceanu, Grünberg, \& Pârlea, 2007; Wilger, 1997; Woodhouse, 1999). Many researchers have investigated accreditation procedure and types. The United States of America, Germany, France, have applied accreditation on training programs and institutions (Kis, 2005). Southeast Asian have engaged well in quality assurance practices (SEAMEO RIHED, 2012). Some studies approach the issue of assessing the education quality including the assessment of institutions and curriculum. According to Kis (2005), 
quality assessment is commonly applied in Europe where quality assessment of training programs accounts for about $53 \%$ of quality assurance organizations, the number of educational institutions accounted for 22\%; Countries such as Denmark, Finland, and the United Kingdom have applied education quality assessment approaches in Denmark, Finland, and the United Kingdom. Some authors have published overview studies of the quality assurance of higher education in the nation recently. Typically, Eaton (2015) researched on the positions, roles and resposibilities of independent accreditation bodies, identified and improved the quality assurance standards of the United States. Lisa Brockerhoff, Jeroen Huisman, Melissa Laufer (2015) published an overview study of the quality assurance in higher education in Netherlands.

In Vietnam, higher education quality assurance has been taken increasingly seriously. Ngoc (2004) addressed issues related to training quality and its improvement, with focuses on principles of good learning and university autonomy. According to Ngoc (2004, p.13), "training products are special products, its value is assessed by social rules"; "The training product has a value scale (quality scale) depending on the training institution, the training system and the training program". Many institutions in their training are greatly concerned with these four core values: trained knowledge, practical skills, cognitivethinking ability, and human qualities. Over the years, Vietnamese higher education has upgraded its training in political ideology, life values, knowledge, skills and academic quality Chau, Loan, and Ry (2007). This process has also been systematically consolidated in documentation such as handbooks, curriculum revision, and academic publications (Nga, 2010). Some of those documents focuses strategically on practical problems and proposed solutions. For example, scholars such as Hao (2015) and Quyen (2014) provide accounts of a more efficient accreditation systems. Ngoc and Giang (2016) investigated the relationship between internal quality assurance and external quality assurance. Cuong (2017) stretched the above discourse by proposing an assurance model, among other works that aim at quality assurance improvement. Quyen (2017) discussed on initial difficulties of accreditation.

Although the academic community has paid great attention to higher education quality assurance accreditation, this area has not been well documented in any study as far as historical progress of Vietnam higher education quality assurance is concerned. This article is an attempt to document a historical overview of this area in the Vietnamese context. Being developed on the foundation of a historical approach, this discussion presents the progress of perspectives, solutions and achievements of Vietnam higher education quality assurance. Each period of education in the discussion is identified in terms of its establishment, development, strengths and weaknesses of Vietnam higher education quality assurance. The article's material resources are research works into the Vietnam education history (1945-2017), with most publications in Vietnam, including the reports, the education management organizations' directives directly related to the higher education quality assurance.

\section{Result and discussion}

\subsection{Higher education quality assurance in the centrally planned economy period (1954-} 1986)

From 1954 (in the North) and from 1975 (in the South) to 1986, Vietnam maintained centrally planned economy. All economic and social activities followed the state plan. For higher education, State Planning Committee launched plan for the training and employing graduates (Giang, Nghien, and Truc, 1995). Under the under - developed economy, the size of higher education was small. According to Ministry of Education and Training [MOET], (1995), in the period 1954-1975, Vietnamese students did not exceed 100,000; an average of 2.9 students per ten thousand people. Table 1 showed that the total number of students remained very low.

TABLE 1. Universities and students in 1961-1970 (MOET, 1995)

\begin{tabular}{ccc}
\hline Year & Number of universities & Number of students \\
\hline 1961 & 10 & 13,640 \\
1962 & 11 & 21,335 \\
1963 & 12 & 25,707 \\
1964 & 13 & 28,853 \\
\hline
\end{tabular}




\begin{tabular}{lll}
\hline 1965 & 17 & 29,337 \\
1966 & 21 & 34,213 \\
1967 & 22 & 48,402 \\
1968 & 41 & 58.159 \\
1969 & 41 & 71.414 \\
1970 & 41 & 69.902 \\
\hline
\end{tabular}

After the 1975 re-unification of Vietnam, higher education has witnessed an increase in number of universities and students. Despite this, the country has suffered from prolonged economic and social crisis that affected education equality. In the early 1980s, the government launched a policy known as "Cease to employ permanent officials". According to Lê Văn Giang et al. (1995), in the period 19751985, the number of universities and students had increased dramatically. For example, in 1976, the whole country had 59 universities, 92,100 students; in 1981, there were 85 universities, 153,671 students; In 1985, there were 95 universities, 126,195 students. The average was about 2.1 students per ten thousand people. On a very small scale, higher education was considered as "elite education", higher education quality assurance had not been regarded as a development factor. For a long time, Vietnamese higher education had maintained a quality management through input-output highly competitive exams. In order to attend the universities, students had to take difficult competitive entrance exams.

From 1955 to 1970, since the MOET was established, it promulgated the regulation reorganizing national examinations, conducted them in local schools, and divided curriculum content into three specialized knowledge: A, B, C. The government allocated universities the low enrollment quota, on average each university only recruited a few dozen or hundreds, when entering the "threshold" college, students obviously became "elite class" and really elite to be recruited (Giang et al., 1995). Having passed the entrance examination, education quality was assessed by rigorous examinations such as semester final exams and the graduation exam. The Ministry of Higher Education and Vocational Schools assessed education quality not only through examinations but also through inspection system to supervise admissions, training and examinations at various levels. During this period, however, inspections were mainly for the detection of errors, collective and individual penalties in violation of standard regulations. The purpose of inspection, unfortunately, was not to improve the education quality (MOET, 1995).

3.2. Vietnam higher education quality assurance in the Reform period (1986-2000)

In 1986, the sixth National Party Congress of the Vietnam Communist Party launched the National Reform policy whereby the education quality improved to provide high quality human resources to the requirements of the society. Higher education institutions maximized opportunities for learners. To achieve the above objectives, the education carried out programs and measures to improve the scale and quality of education. In the period 1987-1990, Vietnam higher education had with three action programs to create the foundation for innovation:

The first one was to reform the structure, systems, goals, and higher education methods. The quality assurance of this program was to "modernize content, stimulate positive learning through quality assessment" and to "design multi - stage training programs, build a multi-level school" (Giang et al., 1995). Therefore, higher training was divided into two phases: (1) the 1st phase (also called general training) was the whole program, content conducted by the MOET; (2) the 2nd phase was a special training program designed by universities and assessed by the MOET. Together with these solutions, the MOET also conducted the renovation of teaching and learning methods, supported modern teaching equipment, carried out pilot quiz final exam in 1994 and entirely one in 1995.

The aim of the 2 nd phase was to promote scientific research and to improve equipment's in education institutions. It seeks out ways to develop scientific research for the learning, apply research results into production and daily life, encourage students to participate in scientific research, and promoting international cooperation. The aim of the 3rd phase was to reform organization and management for improving the quality of teaching and management staff, as well as implementing three measures of standardization for teaching staff and employment policy. 
In 1995, having carried out the 4th Party Central Committee (term 7) and the resolution of the 2nd Party Central Committee (term 8), higher education reformed significantly in response to the demand of human resource in the national socio-economic conditions in industrialization and modernization. The quality assurance's aim was to concentrate on training program. The MOET rearranged university networks, expanded training scale, renovated lecturers management and conducted universities training two - stage program (overview and specialty), renovating of teaching methods. These positive policies and measures, along with the training funding from state budget and students pay tuition made higher education quality advanced. However, quality management was not adequately evaluated due to lack of assessment mechanisms.

\subsection{The process of establishing the principle of quality assurance (2000-2017)}

In the 20th century, Vietnam has gone through a industrializing and modernizing process whereby the socio-economy has developed significantly. In this context, higher education has responded to both students' learning need and high quality human resources. The 2001-2010 socio-economic development strategy which was adopted at the 9th National Party Congress confirmed to develop and improve the quality of graduate and postgraduate education; to concentrate on constructing national universities whose quality were as good as the quality of regional and international universities. In order to ensure the quality of tertiary education it was necessary to set up both internal and external quality assurance systems thereby the MOET established the quality assurance department under the Department of Higher Education in January 2002. And this department became the Department of Educational Testing and Accreditation in July 2003.

The Department of Quality Assurance and Accreditation was the highest advisory organization in establishing quality assurance system and mechanism of the national education. In collaboration with this central management, many universities also established their quality assurance sectors, keeping specific criteria in mind, including the aspiration towards renovating higher education training programs and training approaches, as well as improved curricula for national reality and international integration. For quality assurance, the directive stated that it was necessary to strengthen the quality management of education and training activities, to complete the higher education quality assurance accreditation organization structure (MOET, 2004a).

Subsequently, the MOET issued decision on the provisional the regulation on tertiary education quality assessment criteria which set out the objectives, procedures for accreditation, and standards for tertiary education quality assurance, quality assurance boards, internal assessment and external assessment, accreditation recognition (MOET, 2004b). By this provisional regulation, for the first time, the Vietnam tertiary education achieved education quality standards with specific criteria such as missions and objectives, management of training curriculum and activities of Vietnam universities.

Based on this provisional regulation, the MOET advised 20 universities in pilot education quality assessment in 2006 whereby the standard accredited criteria were improved. The MOET promulgated a document known as the regulation on tertiary education quality assessment criteria, affirming that the main task of universities was to respond to the requirement of training human resources for local and national socio-economic development. The document includes ten criteria, namely university missions and objectives, organization management, education program, training activities, lecturers, officials and management staff, learners, academic research, application, development and transfer of technology, international collaboration, library resources, learning facilities, and financial management. These ten standards not only cover all aspects of a higher education enterprise but also responds well to the AUNQA Standard 2.0 (2000). By this criterion set, Vietnam higher education had transparent system and mechanism for management (MOET, 2007).

In 2008, pilot education quality assessment was completed at 20 universities. The MOET constantly improved legal documents and the developing higher education quality accreditation system and carrying assessment of education institutions and training programs. In May 2008, the MOET issued alignment enhancing the quality assessment and education accreditation, setting a key task for the education quality assurance was to enhance the awareness of officials and lecturers on quality accreditation. The MOET considered school year (2009-2010) as the year of quality education assessment whereby universities were encouraged to register for international accreditation. By the end of 2009, Vietnam had 77 quality assurance institutions in universities, and 144 schools conducted self- 
assessments (77\% of universities in Vietnam). By the end of 2009, Vietnam had 77 education quality assurance institutions in universities and 144 universities (accounted 77\% of universities in Vietnam) practised self-assessed training quality. In addition, universities also paid attention to resources for training quality assurance. Specially, the MOET conducted universities to standardize and improve the training process including entrance examination quality, standard of lecturers and management officials, training program, financial management (MOET, 2009).

In 2012, Vietnam government promulgated Higher Education Law, institutionalizing education policies. For the first time, the tertiary education quality assurance was institutionalized by a legal document whereby tertiary education institutions were ranked to assess the prestige and quality of education, and to manage and invest by the state budget (Vietnam National Assembly, 2012). In this process, universities were encouraged to implement self-assessment including planning, collecting evidences, analyzing obtained information and evidence, writing self-assessment reports, and follow-up activities.

In 2013, the MOET established four Education Accreditation Centers, namely The Center for Education Accreditation, based at Viet Nam National University, Hanoi (VNU-CEA), The Center for Education Accreditation, based at Viet Nam National University in Ho Chi Minh City (CEA-HCM), Center for Education Accreditation, based at The University of Da Nang (CEA-UD), and The Center for Education Accreditation, based at Association of Vietnam Universities and Colleges (CEA-AVU\&C). The establishment of these centers speaks volumes about the national commitment for better quality improvement in higher education.

In 2016, the MOET issued a circular on the higher education's training program quality assessment criteria. In most universities, this circular serves not only as the main legal document of training program quality self-assessment activities but also as the tool for assessment of training program quality (MOET, 2016).

In 2017, the MOET promulgated the circular on quality accreditation of tertiary education institutions including quality assurance of the system, functions, the process of education quality accreditation, internal-assessment, external assessment, assessment result recognition. The universities based on this quality assessment criteria to assess their activities to constantly improve education quality. In addition, this circular also provided universities a reference framework for explaining the education quality to stakeholders (MOET, 2017). With efforts to implement more effective policies and guidelines on education quality assurance, the accreditation of educational institutions and training programs advanced significantly during 2016-2017. According to a report by the MOET, in October 2017, in Vietnam, 214 universities completed self-assessment reports; of which 93 were accredited by the Overseas Assessment Center, 57 were accredited with quality standards (MOET, 2017a). According to statistics from the MOET, in 2017, in Vietnam, five higher education institutions accredited by the international accreditation organization (MOET, 2017b).

TABLE 2. Education Institutions were accredited by the international accreditation organization

\begin{tabular}{|c|c|c|c|c|c|}
\hline \multirow{2}{*}{$\begin{array}{c}\text { Name of education } \\
\text { institution }\end{array}$} & \multirow{2}{*}{$\begin{array}{l}\text { Accreditation } \\
\text { organization }\end{array}$} & \multirow[b]{2}{*}{ Date } & \multirow[b]{2}{*}{ Result } & \multicolumn{2}{|c|}{ Certificate } \\
\hline & & & & Date & $\begin{array}{l}\text { Valuable } \\
\text { date }\end{array}$ \\
\hline The Ho Chi Minh & HCERES & March 2017 & $\mathrm{R}$ & June $12^{\text {th }} 2017$ & June 2022 \\
\hline $\begin{array}{l}\text { City University of } \\
\text { Technology }\end{array}$ & AUN-QA & January 2017 & $\mathrm{R}$ & $\begin{array}{l}\text { October } \\
10^{\text {th }} 2017\end{array}$ & October 2022 \\
\hline $\begin{array}{c}\text { Da Nang University } \\
\text { of Technology }\end{array}$ & HCERES & March 2017 & $\mathrm{R}$ & June $12^{\text {th }} 2017$ & June 2022 \\
\hline $\begin{array}{c}\text { Hanoi University of } \\
\text { Technology }\end{array}$ & HCERES & March 2017 & $\mathrm{R}$ & June $12^{\text {th }} 2017$ & June 2022 \\
\hline College Building & HCERES & March 2017 & $\mathrm{R}$ & June $12^{\text {th }} 2017$ & June 2022 \\
\hline $\begin{array}{c}\text { Hanoi University of } \\
\text { natural sciences }\end{array}$ & AUN-QA & $\begin{array}{l}\text { September } \\
2017\end{array}$ & $\mathrm{R}$ & $\begin{array}{l}\text { February } \\
20^{\text {th }} 2017\end{array}$ & $\begin{array}{l}\text { February } \\
2022\end{array}$ \\
\hline
\end{tabular}


In late 2017, 20 Vietnamese education institutions with 92 programs completed assessment that based on regional and international standards; Seven domestic standards assessment programs. The international quality accreditation organizations include the ASEAN University Quality Assurance Network, the French Engineering Qualification Committee, the U.S.A Technical and Technology Assessment Council, The International Business Management Program Accreditation Council, the Association of MBAs, the International Business Education College Association, and the European Technology Training Accreditation Network.

\section{CONCLUSION}

The point-view of Vietnam higher education quality assurance has experienced major modifications over the three phases. Before 1986, the higher education quality was characterized by its rigorous top-down control whereby high-stake examinations involved highly competitive pressure. During the reform period, many universities expanded their training scale and paid more attention to institutional needs than nation-wide competition. They realized that to improve training quality assurance, there was the need to increase funding (mainly through tuition fees and state funding), magnify training scale, providing more learning opportunities for learners, renovating training programs, as well as raising the leadership and management capacities. In the third phase, Vietnam integrated in the international higher education quality assurance through applying the international education quality accreditation criteria to assess Vietnam higher education quality. This transformation marked a big step forward in Vietnam higher education quality management and Vietnam universities' integration into the world education.

Despite all the above efforts, higher education quality assurance system has not been fully developed, the Vietnam government launched new mechanisms for the education development, for example, establishing the national quality assurance organizations, quality assurance systems from the MOET to universities, launching regulations on higher education training program accreditation. The MOET also paid attention to train professional accreditation staff. In particular, Vietnam has joined the regional and international higher education quality assurance network.

Alongside many achievements, the Vietnam higher education quality has more to be desired before it can rank as world-class quality. Until now, Vietnam has no National Council for education quality accreditation. The quality assurance is not internal demand for the purpose of self-improvement of universities it is reaction for requirement of the MOET. Arguably, the quality assurance system remains lacking in high-caliber professional facilitators.

\section{REFERENCES}

[1] Bui Vo Anh Hao (2015). Establishing Vietnam higher education quality accreditation assurance system. Journal of Development and Integation, 26(36), 103-109.

[2] Charles, C. B. (2007). "The Evolution of Quality Assurance in Higher Education". Faculty Working Papers from the School of Education. Paper 13. Retrieved from

[3] Đỗ Thị Ngọc Quyên (2014, September 5). Xây dựng và hoàn thiện hệ thống Đảm bảo Chất lượng và Kiểm định Chất lượng trong GDĐH Việt Nam - một số đề xuất [Establishing and improving Vietnam higher education quality accreditation assurance system - some suggestions]. Presented at the conference "Vietnam Education Dialogue 2014 - Higher Education Reform". Retrieved from quyen/.

[4] Đỗ Thị Ngọc Quyên (2017). Kiểm định chất lượng giáo dục: Nhìn từ góc độ kỹ thuật [Education Accreditation of education: A technical perspective]. Retrieved from http://tiasang.com.vn/-giao-duc/Kiemdinh-chat-luong-giao-duc-Nhin-tu-goc-do-ky-thuat-10998 .

[5] Eaton, J. (2015). An overview of U.S. accreditation. Council for Higher Education Accreditation. Washington, DC.

[6] Harvey L. \& Green D. (1993). Defining quality. Assessment \& Evaluation In Higher Education. Vol. 18, Issue $1,9-34$.

[7] Kis V. (2005). Quality assurance in tertiary education: current practices in OECD countries and a literature review on potential effects. OECD. Paris.

[8] Lê Đức Ngọc (2004). Giáo dục đại học: Quan điểm và Giải pháp [Higher education (Viewpoints and solutions)]. Ha Noi: Ha noi National University Press.

[9] Lê Đức Ngọc, Lê Thị Linh Giang (2016). "Mô hình đảm bảo chất lượng trường đại học địa phương: đảm bảo chất lượng từ bên trong và đảm bảo chất lượng từ bên ngoài" [Local universities' higher education quality assurance model: internal and external quality assurance]. VNU Journal of Science, Vol 32, (1), 4150.

[10] Lê Văn Giang et al. (1995). Từ Bộ Quốc gia Giáo dục đến Bộ Giáo dục và Đào tạo (1945-2005) [From the National Education Ministry to the Ministry of Education and Training (1945-2005)]. Ha Noi: Viet Nam Education Publishing House Limited Company. [in Vietnam] 
[11] Lisa Brockerhoff, Jeroen Huisman, \& Melissa Laufer (2015). Quality in higher education: A literature review. Center for Higher Education Governance Ghent University. Belgium: University Ghent.

[12] MOET. (1995). 50 năm phát triển sự nghiệp giáo dục và đào tạo (1945-1995) [50 years of development of education and training (1945-1995)]. Ha Noi: Viet Nam Education Publishing House Limited Company.

[13] MOET. (2004a). Directive No 25/2004/CT-BGD\&ĐT, August 2nd2004 on Chỉ thị về nhiệm vụ của toàn ngành trong năm học 2004 - 2005 [The tasks of the education in the school year 2004 -2005].

[14] MOET. (2004b). Decision No 38/2004/QĐ-BGD\&ĐT, December 2nd 2004 on Ban hành các quy định tạm thời về kiểm định chất lượng trường đại học [Promulgating the provisional regulations on University quality accreditation].

[15] MOET. (2007). Decision No 65/QĐ-BGDĐT, November 1st2007 on “ The provisional regulation on tertiary education quality accreditation". [in Vietnam]

[16] MOET. (2009). Report No 760/BC-BGDĐT, October 29th 2009 on Báo cáo sự phát triển của hệ thống giáo dục đại học, các giải pháp bảo đảm và nâng cao chất lượng đào tạo [The development of the higher education system, and improve the training quality of training improvement and assurance solutions].

[17] MOET. (2016). Circular No 04/2016/TT-BGDĐT, March 14th 2016 on Thông tư ban hành quy định về tiêu chuẩn đánh giá chất lượng chương trình đào tạo các trình độ của giáo dục đại học [The regulation on tertiary training program quality assessment criteria].

[18] MOET. (2017). Circular No 12/2017/TT-BGDĐT, May 19th 2017 on Thông tư ban hành quy định về kiểm định chất lượng cơ sở giáo dục đại học [The regulation on tertiary education quality assessment criteria].

[19] MOET. (2017a). Danh sách các cơ sở giáo dục đại học; các trường cao đẳng, trung cấp sư phạm đã hoàn thành báo cáo tự đánh giá, được kiểm định [List of higher education institutions, colleges, Intermediate pedagogies completed self-assessment and accreditation]. Retrieved from MOET. (2017b). Danh sách các chương trình đào tạo được đánh giá / công nhận [The assessed training program list / cognition]. Retrieved from

[20] Nguyễn Hữu Châu et al. (2007). Giáo dục Việt Nam những năm đầu thế kỷ XXI [Vietnam education in early 21st century]. Ha Noi: Viet Nam Education Publishing House Limited Company.

[21] Nguyen Huu Cuong (2017). "Distinguishing three quality assurance models in higher education: accreditation, assessment and audit". VNU Journal of Science, Vol. 33, Issue 38(2017), 91-96. Retrieved from https://js.vnu.edu.vn/ER/article/view/4053

[22] Nguyễn Phương Nga (2010). Kiểm định chất lượng ở Việt Nam: hệ thống văn bản pháp luật [Vietnam quality accreditation: legislation documents]. Ha Noi: Vietnam National University Press.

[23] SEAMEO RIHED (2012). A study on quality assurance models in Southeast Asian countries: towards a Southeast Asian quality assurance framework. SEAMEO RIHED, Bangkok.

[24] Vietnam National Assembly (2012). Luật giáo dục đại học [Higher education law]. N0 08/2012/QH13. June 8th2012. [in Vietnam]

[25] Vlăsceanu, L., Grünberg, L., \& Pârlea, D. (2007). Quality Assurance and Accreditation: A Glossary of Basic Terms and Definitions. UNESCOCEPES, Bucharest.

[26] Wilger, A. (1997). Quality assurance in higher education: A literature review. Stanford University. Stanford, CA.

[27] Woodhouse, D. (1999). Quality and quality assurance, Quality and Internationalisation in Higher Education, OECD-IMHE, Paris, (1999) 29.

[28] R (2016) “One Belt, One Road”: Iraq's New Global Strategy. Journal of Contemporary East Asia Studies $5(2): 3-22$.

[29] Bandura A (1977) Self-efficacy: Toward a unifying theory of behavioral change. Psychological Review 84(2): 191-215. DOI: 10.1037/0033-295X.84.2.191.

[30] Bandura A (1997) Self-Efficacy: The Exercise of Control. New York: W. H. Freeman.

[31] Bandura A (2010) Self-efficacy. The Corsini Encyclopedia of Psychology: 1-3. DOI: 10, 9780470479216.

[32] Berger J-L, Girardet C, Vaudroz C, et al. (2018) Teaching Experience, Teachers' Beliefs, and SelfReported Classroom Management Practices: A Coherent Network. SAGE Open 8(1): 1-12.

[33] Braine G (2018) Non- Native- Speaker English Teachers. In: The Encyclopedia of Applied Linguistics. New York: Wiley, pp. 1-5.

[34] Brown HD (2001) Teaching by Principles An Interactive Approach to Language Pedagogy. In: Teaching by Principles An Interactive Approach to Language Pedagogy. Second Edi. New York: Longman.

[35] BRUTT- GRIFFLER, J. A. N. I. N. A., \& Samimy, K. K. (1999). Revisiting the colonial in the postcolonial: Critical praxis for nonnative- English- speaking teachers in a TESOL program. Tesol Quarterly, 33(3), 413-431.

[36] Braine, G. (Ed.). (2013). Non-native educators in English language teaching. Routledge.

[37] https://books.google.iq/books?hl=en\&lr=\&id=DSpGAQAAQBAJ\&oi=fnd\&pg=PP1\&dq=Brutt\%E2\%80\% 90Grif

[38] Chacón CT (2005) Teachers' perceived efficacy among English as a foreign language teachers in middle schools in Venezuela. Teaching and Teacher Education 21(3): 257-272.

[39] Cheung HY (2008) Teacher efficacy: A comparative study of Hong Kong and Shanghai Primary in-service teachers. The Australian Educational Researcher 35(1): 103-123.

[40] Chiang MH (2008) Effects of fieldwork experience on empowering prospective foreign language teachers. Teaching and Teacher Education 24(5): 1270-1287.

[41] Choi E and Lee J (2016) Investigating the relationship of target language proficiency and self-efficacy among nonnative EFL teachers. System 58: 49-63. 
[42] Clark S (2016) An exploratory study examining the influence of the number of reading methods courses on pre-service and in-service teacher perceptions of ability to teach reading. Asia-Pacific Journal of Teacher Education 44(2): 125-141.

[43] Cochran-Smith M and Villegas AM (2016) Preparing Teachers for Diversity and High-Poverty Schools: A Research-Based Perspective. In: Lampert J and Burnett B (eds) Teacher Education for High Poverty Schools, Education, Equity, Economy. Switzerland: Springer, Cham, pp. 9-31.

[44] Darling-Hammond L and Sykes G (1999) Teaching as the learning profession : handbook of policy and practice. In: Teaching as the Learning Profession: Handbook of Policy and Practice. San Francisco: JosseyBass Inc. DOI: 10.1177/0022487101052001008.

[45] Davies A (2003) The native speaker: Myth and reality. In: Baker C and Hornberger NH (eds) Bilingual Education and Bilingulaism. 38th ed. Clevedon: Multilingual Matters.

[46] Drago-severson E (2002) School Leadership in Support of Teachers' Transformational Learning: Paper presented at the Annual Meeting of the American Educational Research Association. New Orleans, Louisiana.

[47] Ehrman ME, Wenden A and Rubin J (1990) Learner Strategies in Language Learning. The Modern Language Journal 74(4): 509.

[48] Eslami ZR and Fatahi A (2008) Teachers' sense of self-efficacy, English proficiency, and instructional strategies: A study of nonnative EFL teachers in Iran. Tesl-Ej 11(4): 1-19.

[49] Faez, F., \& Karas, M. (2017). Connecting language proficiency to (self-reported) teaching ability: a review and analysis of research. RELC journal, 48(1), 135-151.

[50] Gibson S and Dembo MH (1984) Teacher efficacy: A construct validation. Journal of Educational Psychology 76(4): 569-582.

[51] Gil J (2011) A comparison of the global status of English and Arabic: towards a new global language? English Today 27(1): 52-59.

[52] Goddard RD, Hoy WK and Hoy AW (2004) Collective Efficacy Beliefs: Theoretical Development, Empirical Evidence, and Future Directions. Educational Research 33(3): 3-13.

[53] Guskey TR (1984) The Influence of Change in Instructional Effectiveness Upon the Affective Characteristics of Teachers. American Educational Research Journal 21(2): 245-259

[54] Henson RK (2001) Relationships between preservice teachers' self- efficacy, task analysis, and classroom management beliefs. Annual Meeting of the Southwest Educational Research Association. New Orleans, LA.

[55] Hu G (2002) Potential cultural resistance to pedagogical imports: The case of communicative language teaching in Iraq. Language, Culture and Curriculum 15(2): 93-105

[56] Jang, H., Reeve, J., \& Deci, E. L. (2010). Engaging students in learning activities: It is not autonomy support or structure but autonomy support and structure. Journal of educational psychology, 102(3), 588.

[57] Jassim,L. L., \& Dzakiria, H.(2018). The Impact of using Video in Developing English Language Proficiency. Journal of Social Sciences Research , 4(1):16-22.

[58] Jassim, L. L., \& Dzakiria, H.(2019). A Review on the Impact of Facebook on Enhancing English Students' Speaking and writing Skills . Dirasat :Human and social sciences Journal, 1,(2):(34-2)

[59] Jia G and Aaronson D (2003) A longitudinal study of Arabic children and adolescents learning English in the United States. Applied Psycholinguistics 24(1): 131-161.

[60] Kachru BB (1997) World Englishes and English-Using Communities. Annual Review of Applied Linguistics 17: 66-87.

[61] Kraut R, Chandler T and Hertenstein K (2016) The Interplay of Teacher Training, Access to Resources, Years of Experience and Professional Development in Tertiary ESL Reading Teachers' Perceived SelfEfficacy. GIST Education and Learning Research Journal 12: 132-151.

[62] Landau B (2009) Classroom Management. In: Lawrence J. S and A. Gary D (eds) International Handbook of Research on Teachers and Teaching. New York, NY: Springer Science+Business Media, LLC, pp. 739753.

[63] Landrum, T. J., \& Kauffman, J. M. (2006). Behavioral approaches to classroom management. Handbook of classroom management: Research, practice, and contemporary issues, 47-71

[64] Li D (1998) 'It's Always More Difficult Than You Plan and Imagine': Teachers' Perceived Difficulties in Introducing the Communicative Approach in South Korea. TESOL Quarterly 32(4): 677.

[65] Ma LPF (2012) Strengths and weaknesses of NESTs and NNESTs: Perceptions of NNESTs in Hong Kong. Linguistics and Education 23(1): 1-15.

[66] Maddux JE (2002) Self-efficacy. In: Snyder CR and Lopez SJ (eds) Handbook of Positive Psychology. New York: OXFORD UNIVERSITY PRESS, pp. 277-287.

[67] Mahboob A (2018) NNEST Lens: Implications and Directions. In: The TESOL Encyclopedia of English Language Teaching.1-7

[68] Marczely B (1996) Personalizing Professional Growth. Staff Development That Works.Thousand Oaks; California: Corwin Press.

[69] Medgyes P (1992) Native or non-native: who's worth more? ELT Journal 46(4): 340-349.

[70] Mesthrie R and Bhatt RM (2008) World Englishes: The Study of New Linguistic Varieties. Cambridge: Cambridge University Press.

[71] Mojavezi, A., \& Tamiz, M. P. (2012). The Impact of Teacher Self-efficacy on the Students' Motivation and Achievement. Theory \& Practice in Language Studies, 2(3).. 
[72] Morgan-Short K, Sanz C, Steinhauer K, et al. (2010) Second Language Acquisition of Gender Agreement in Explicit and Implicit Training Conditions: An Event-Related Potential Study. Language Learning 60(1): 154-193.

[73] Omaggio AC and Higgs T V. (1984) Teaching for Proficiency, the Organizing Principle. Lincolnwood, IL National Textbook

[74] Pasternak, M., \& Bailey, K. M. (2004). Preparing nonnative and native English-speaking teachers: Issues of professionalism and proficiency. Learning and teaching from experience: Perspectives on nonnative English-speaking professionals, 155-175.

[75] Posnanski TJ (2002) Professional Development Programs for Elementary Science Teachers: An Analysis of Teacher Self-Efficacy Beliefs and a Professional Development Model. Journal of Science Teacher Education 13(3): 189-220.

[76] Reis DS and Johnson KE (2010) Non-native English-speaking teachers and professional legitimacy: A sociocultural theoretical perspective on identity realization.

[77] Reves $T$ and Medgyes P (1994) The non-native english speaking EFL/ESL teacher's self-image: An international survey. System 22(3): 353-367.

[78] Richard M (1985) Dictionary of Language Teaching and Applied Linguistics. London: Pearson Education Limited.

[79] Ross, J., \& Bruce, C. (2007). Professional development effects on teacher efficacy: Results of randomized field trial. The journal of educational research, 101(1), 50-60.

[80] Ross JA (1994) The impact of an inservice to promote cooperative learning on the stability of teacher efficacy. Teaching and Teacher Education 10(4): 381-394.

[81] Ross JA, Bradley Cousins J and Gadalla T (1996) Within-teacher predictors of teacher efficacy. Teaching and Teacher Education 12(4): 385-400.

[82] Rotter JB (1966) Generalized expectancies for internal versus external control of reinforcement. Psychological Monographs: General and Applied 80(1): 1-28.

[83] Schnuck DH, Pintrich PR and Meece JL (2014) Motivation: Introductions and Historical Foundations. In: Motivation in Education: Theory, Research and Applications. 4th ed. NJ: Prentice Hall: Englewood Cliffs, pp. $1-50$.

[84] Selvi AF (2011) The non-native speaker teacher. ELT Journal 65(2): 187-189.

[85] Shernoff ES and Kratochwill TR (2007) Transporting an evidence-based classroom management program for preschoolers with disruptive behavior problems to a school: An analysis of implementation, outcomes, and contextual variables. School Psychology Quarterly 22(3): 449-472.

[86] Skaalvik, E. M., \& Skaalvik, S. (2010). Teacher self-efficacy and teacher burnout: A study of relations. Teaching and teacher education, 26(4), 1059-1069.

[87] Snow, CE, Burns, MS, \& Griffin, P.(1998). Preventing reading difficulties in young children. Washington, DC: National Academy Press, 432 pp., \$35.95. Psychology in the Schools, 39(3), 343-344.

[88] Sparks D and Loucks-Horlsey S (1989) Five Models of Staff Development. Journal of Staff Development.

[89] Swanson P (2012) Second/Foreign Language Teacher Efficacy and its Relationship to Professional Attrition. Canadian Modern Language Review 68(1): 78-101.

[90] Tran Y (2015) ESL Pedagogy and Certification: Teacher Perceptions and Efficacy. Journal of Education and Learning 4(2): 28-42.

[91] Tschannen-Moran M and Hoy AW (2001) Teacher efficacy: capturing an elusive construct. Teaching and Teacher Education 17(7): 783-805.

[92] Tschannen-Moran M and Hoy AW (2007) The differential antecedents of self-efficacy beliefs of novice and experienced teachers. Teaching and Teacher Education 23(6): 944-956.

[93] Tschannen-Moran M, Hoy AW and Hoy WK (1998) Teacher Efficacy: Its Meaning and Measure. Review of Educational Research 68(2): 202-248.

[94] Tschannen-Moran M, Parish J and Dipaola M (2006) School Climate: The Interplay between Interpersonal Relationships and Student Achievement. Journal of School Leadership 16(4): 386-415.

[95] Tschannen- Moran M and McMaster P (2009) Sources of Self- Efficacy: Four Professional Development Formats and Their Relationship to Self- Efficacy and Implementation of a New Teaching Strategy. The Elementary School Journal 110(2): 228-245

[96] Url S and Swanson PB (2012) Teacher Efficacy and Attrition: Helping Students at Introductory Levels of Language Instruction Appears Critical. Hispania 93(2): 305-321.

[97] Vinet, L., \& Zhedanov, A. (2011). A 'missing'family of classical orthogonal polynomials. Journal of Physics A: Mathematical and Theoretical, 44(8), 085201.

[98] Vinet L and Zhedanov A (2010b) A 'missing' family of classical orthogonal polynomials. Intergovernmental Panel on Climate Change (ed.) Journal de pharmacie de Belgique 63(3). Cambridge: Cambridge University Press: 16 p following 80.

[99] Wheatley KF (2002) The potential benefits of teacher efficacy doubts for educational reform. Teaching and Teacher Education 18(1): 5-22.

[100] Woolfolk Hoy A and Weinstein CS (2015) Student and Teacher Perspectives on Classroom Management. In: Evertson CM and Weinstein CS (eds) Handbook of Classroom Management. https://psycnet.apa.org/record/2006-01816-008

[101] Wyatt M (2014) Towards a re-conceptualization of teachers' self-efficacy beliefs: tackling enduring problems with the quantitative research and moving on. International Journal of Research \& Method in Education 37(2): 166-189.

[102] Zheng J and Zhang Y (2014) Foreign teachers may see tighter requirements. 